\title{
THE DIVERSITY OF HOUSING TYPOLOGIES IN THE SERVICE OF THE COMPLEXIFICATION OF INHABITANT'S NEEDS AND EXPECTATIONS Observations in the heart of Hainaut
}

\author{
Author(s) / Auteur(s) : \\ Authors : Ornella VANZANDE and Jean-Alexandre POULEUR Traduction Céline Finzinger \\ Contact details: \\ Ornella VANZANDE \\ Reasearch Assistant \\ Faculty of Architecture and Urbanism, UMONS \\ ornella.vanzande@umons.ac.be
}

Big changes constantly disrupt the society and the world. Populations evolve as well as in their lifestyles as in their ideals. Based on the INSEE survey data, Yvonne Bernard ${ }^{1}$ has clearly identified those evolutions since the nineties. These social transformations influence the lifestyles within the habitat: the generalisation of woman's work, the modifications of the family group (emergence of a large number of single-parent families, recomposed families, person living alone...) and the reduction of working hours (involving spending more time at home), including the flexibility of use (influenced for instance by the «work at home » which implies the organisation of a work place within the household) cause changes in the way of inhabiting. "Ainsi la forme de l'habitat et son évolution reflètent très largement celle des mentalités, des moyens d'existence et des modes de vie. $»^{2}$ A difference can also be seen between generations: while for the old generations, the habitat is constituted by private and public spaces clearly differentiated (room dedicated to the everyday life - room dedicated to the family - room dedicated to couple's intimacy), for the young's, spaces tend to interweave, they open up. ${ }^{3}$ Not to mention the important demographic evolution that we are facing. There are two reasons for this evolution. Whereas life expectancy is increasing (resulting in a more and more long life), the number and the proportion of old people in the population increase. ${ }^{4}$ In addition to those changes, energy needs complicate the whole. The current standards are still little respected: the existing housing stock suffers from critical gaps in terms of energy savings and comfort. But also from problems linked to the financial aspect: a more and more precarious society, difficulties to become landlord, social authorities more and more solicited for social housings construction... In some cities (and even more in the study area specifically targeted: the center-Mons-Borinage), the population has important financial difficulties which does not foster the access to a correct and decent housing. Therefore it is required to rethink housing; to innovate in order to find adaptative solutions for everyones. Housing and its

\footnotetext{
1 BERNARD Yvonne L'habitat à l'épreuve de la réalité pratique. Quelques hypothèses prospectives [online] http://www.habiter-autrement.org/01_tendances/06_tend.htm (consulté le 1509 2015)

${ }^{2}$ ROULEAU Bernard, définition de l'habitat. In : Pierre Merlin et Françoise Choay, Dictionnaire de l'urbanisme et de l'aménagement, presses universitaires de France, 1988, p 392 que nous proposons de traduire par: Therefore the form of habitat and its evolution reflect widely the one of mentalities, livelihoods and lifestyles

${ }^{3}$ DREYER Pascal, Limiter les conséquences de la vieillesse et de la dépendance, Agir sur l'habitat et l'environnement. [online] In : Gérontologie et société, 2008/2, Fond. Nationale de Gérontologie - n 125 URL : http://www.cairn.info/revuegerontologie-et-societe-2008-2-p-167.htm (consulted on the 20/09/2015).

${ }^{4}$ CHARLOT V., COBBAUT N., DE METS J., HINNEKINT B., LAMBERT M. pour LA FONDATION ROI BAUDOUIN, «La maison de repos du 21 ième siècle. Un lieu de vie convivial, soins inclus. À l'écoute des résidents, du personnel, de la direction, des experts. Suggestions et exemples de nouvelles initiatives », $p 16$ [online] URL : http://www.uclouvain.be/cps/ucl/doc/aisbl-generations/documents/DocPart_Habit_MaisonRepos21eSiecle_2009.pdf (consulted on the 23/10/2013)
} 
conception methods have to evolve with the social changes in order to answer the new and deeply more complex needs generated by it.

First of all, although it is built on a theorical architectural framework, it is an empirical research method. The research is continously implemented by evolutions and new trends in terms of habitat's space composition through press review ${ }^{5}$ and site visits. Examples are collated for the purpose of understanding the caracteristics of the emergent and leading typologies.

This construction of typologies is based on the cross-checking of an observation of the leading housing forms that seem to extend an out-of-date industrial production from the $19^{\text {th }}$ century and of alternative habitat forms that inspire an updating of Durand's concept. Would this updating of the typological concept and especially of its use allow to better consider the changes in the current needs? By extending the classical field of survey and by an adaptation of the mechanisms in the use of the typologies inspired by Lucan, we suggest to switch from a causal perspective of the space composition to a systemic-approach allowing for a greater consideration for the growing complexification of the expectations.

\section{HOUSING TYPOLOGIES AS CURRENTLY DEFINED}

But what is a housing?

The tacit definition of what a housing is, strongly induced the observation. It seems that we associate to the housing the "popular » Larousse definition: "Partie d'un immeuble, d'une maison, où l'on habite. » ${ }^{6}$ The image of the house or the apartment building seems to stick to the one of the housing.

The consultation of sales offers in estate agencies shows in an exemplary way that perception. This restriction of the notion of housing generates a small variety of housing types offered for sale. Little housing typologies are distinguished: essentially villas and single-family homes as well as apartments rarely combined with other types. The "Guide ${ }^{7} \mathrm{~d}^{\text {' }}$ architecture moderne et contemporaine" (Modern and Contemporary Architecture Guide, literally translated in English) is a nice example of inventory resuming a set of innovative architectural examples on the territory of the heart of Hainaut, aiming at identifying the richness of the innovative architectural production. The interest of the Guide for our analysis is to present for most of the buildings a plan view. This type of presentation allows to observe the development of some original housing programming especially focused on the integration of an office, a medical practice office or an artist's studio. But nevertheless the traditional housing programming dominates and cases that combine several different housing types answering the social issues previously identified (ageing population, reduction of the family size, impoverishment...) are very rare. Only an exemple of kangaroo habitat as well as the one of a single-family house associated with student accomodations stand out. Even the most experienced architects (which incidentally are not responsible for the programming) generate only a little variety of housing types with respect to what is observable on this territory. The main originality of the architects seems more formal than programmatic. A statement probably extrapolatable to other territories.

\footnotetext{
${ }^{5}$ Selected from a series of key words such as « habitat », « housing », « society evolution », « architecture and urbanism »,...

6 "Section of a building, of a house where we live." Larousse, computerized version, [online], URL : http://www.larousse.fr/dictionnaires/francais/logement/47655 (consulted on the 27/09/2015)

${ }^{7}$ DESMEDT I., BEN DJAFFAR L., Guide d'architecture moderne et contemporaine 1885-2015, Mons et cœur du Hainaut, Ed. Mardaga and the architecture section of the Federation of Wallonia-Brussels, 2015.
} 
Apparently there is on the market essentially: single dwellings (as villas, semi-detached houses and attached houses); collective dwellings matching individual households (apartments); as well as collective dwellings regrouping sometimes within a same unit an important population (nursing homes, educational institutions, specialized hospitals, prisons, etc). The table below ${ }^{8}$ shows the group of basic typologies spread out on the territory as well as the type of families living in those dwellings. It tends to bring to light the causal link between the household types and the architectural typologies existing in majority on the territory (which could be opposed to systemic links creating combinations, agreements and hybridizations between the same elements developed later). A domination of the individual housing with a trend for the elderly persons to frequent adapted housings such as the nursing home at end-of-life.

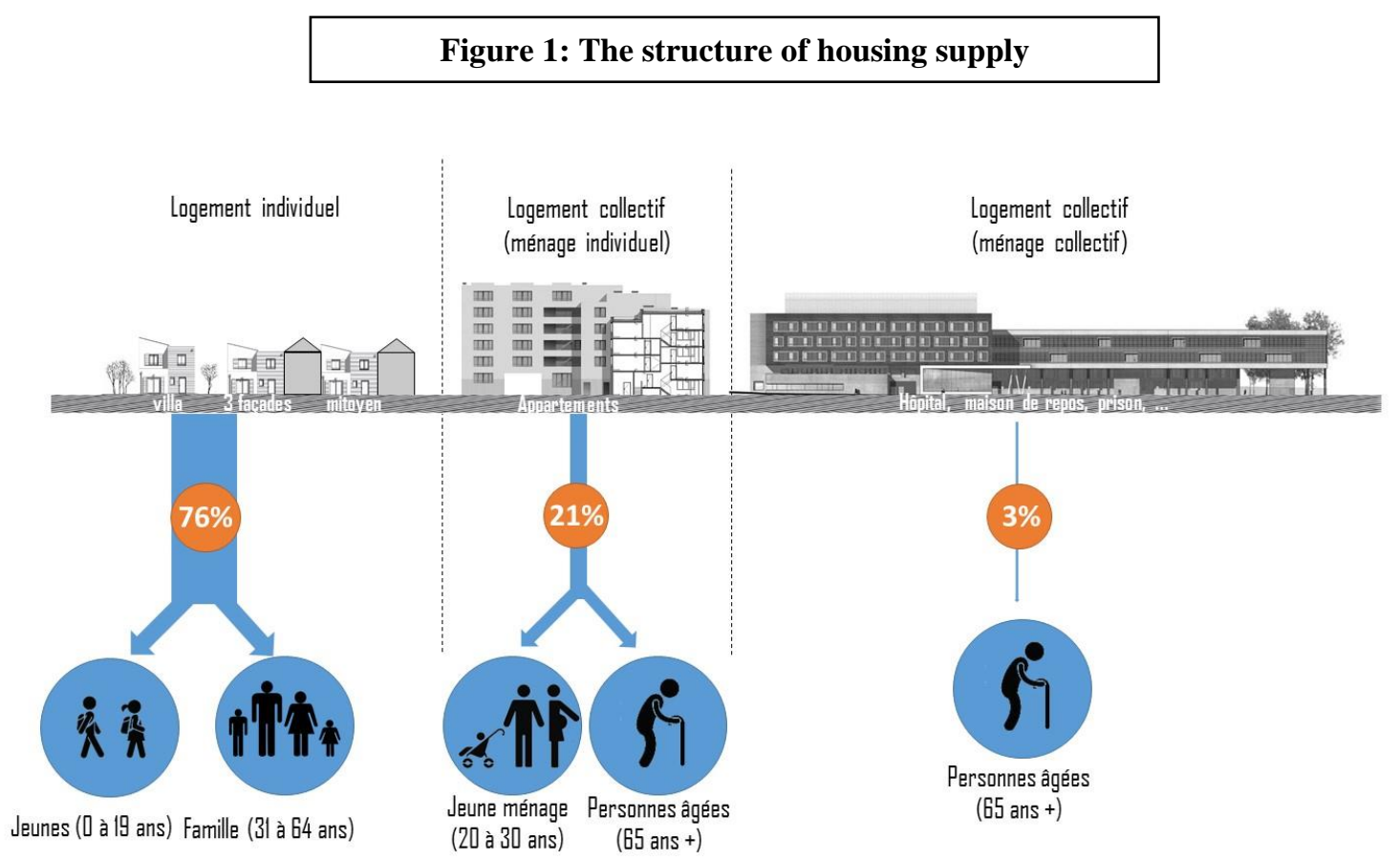

Figure 1: Typology of the current housings

Individual housing ::.:.:.:.::Multi-family building (individual household)::.::*:::::Multi-family building (collective household)

Joung's (0 to 19 years old)

Family (31 to 64 years old)

Young household (20 to 30 years old)

Working persons (20 to 65 years old)

Elderly persons $(65$ years old + )

The NSI's statistics confirm this housing structure ${ }^{9}$ : distinguishing essentially single-family house (detached, semi-detached or attached), apartment, and studio. Single-family houses

\footnotetext{
${ }^{8}$ Schematization of the causal relations, between leading typologies on the territory and social profiles, detected through the offer promotion.

${ }^{9}$ NSI STATISTICS DATA « Private housings occupied according to the housing type and to the building type » Table 00,40 2001
} 
represent $76 \%$ of the housing (of which $43 \%$ is attached) and apartments $21 \%$. There would be therefore only $3 \%$ of alternatives to these two main forms! ${ }^{10}$ These statistics don't necessarily integrate homeless, illegals and hardly allow identifying all maladjustment generated by those housing types.

At the moment, the dream of many Belgians is still the detached villa remote out of the citycentre... Not only the production is focused on a particular type but we notice also that turnkey companies take more or less $61 \%^{11}$ of the individual housing construction market. Those companies reinforce the production of standardized architecture and little diversification. ${ }^{12}$ It generates other problems on the territory scale: all the statistical indicators prove it: the urban explosion continues to grow in Belgium. According to the 2001 Housing Census results, the proportion of single-family housing was still progressing during the decade 1991-2001 (+2,6\%), notably by the increasing number of low-density housing $(+0,3 \%)$. This will to build in residential suburbs has grown despite the crisis; provoking the weakening of the activities around the urban centres, in favour of the development of middlesized cities or rural areas adjacent to big cities, maintaining this way "the negative effects more and more severe in terms of transports (cost and time), environment et state over-costs on collective equipment and road infrastructure." ${ }^{13}$ Simultaneously some main quarters in the heart of the cities comprise old buildings and progressively fall into ruin. "Constituted mainly by private properties that are leased, this housing stock runs down or get reduced gradually as a part of the upper and middle-class leave the cities and as speculative projects are compounded particularly in Brussels. In this way, a part of the private stock gets transformed in residual housings (de facto social housing) for the working classes that can not access the new residential construction market but also for the foreign population arrived in the fifties." 14 Is this state reversible or is Belgium condemned to become a gigantic periphery zone mono-functional with a mono-type architecture?

At first sight, the current housing market exploits very little the housing diversity. Though society and its needs are in constant mutations and there is an increasing multiplication of family profiles. We face also a serious increase of elderly people; will they live in this mass of isolated housings that are still widely taking shape?

Simultanemously, many problems appears from new constructions. A gap between citizen lifestyle and innovations chosen by experts without consulting the population can be

\footnotetext{
${ }^{10}$ VANNESTE D., THOMAS I., GOOSSENS L., Le logement en Belgique : enquête socio-économique 2001. [online] URL : http://statbel.fgov.be/fr/binaries/mono_200102_fr\%5B1\%5D_tcm326-35799.pdf. (consulted on the 27/09/2015). They can be hidden behind the "other » types or behind the "no answer to the question » knowing that the initial categories of the questionnaire might have prevent the person answering to adequately define the type of his housing.

${ }^{11}$ COENE G., VANHEE N., Construire ou rénover: plaisir ou fardeau, In : Test achat (mise en ligne 01/03/2006) URL: http://www.test-achats.be/maison-energie/nc/article/notre-grande-enquete-sur-la-construction. (consulted on the 26/09/2015).

12 VANDAMME Thomas, Le contexte de la maison individuelle en Belgique, Faculté d'Architecture et d'Urbanisme de l'université de Mons, mémoire en vue de l'obtention du diplôme d'architecture, 2014

${ }^{13}$ DESSOUROUX C., ROMAINVILLE A., La production de logements en Belgique et à Bruxelles - Acteurs, dynamiques, géographie, [EN LIGNE] In: EchoGeo, 15|2011: décembre 2010/février 2011, URL: https://echogeo.revues.org/12279?lang=en (consulted on the 26/09/2015).

14 DESSOUROUX C., ROMAINVILLE A, ibid.
} 
observed $^{15}$. This new and imposed way of inhabitating, despite being ecological and in favor of the planet, generates various problems such as the use of a green wall that increases insects invasion on balconies up inside the dwellings, the floor dry cleaning or the setting up of standby switches which should be a simple energy saving technique is actually also an everyday problem (such as the automatic extinction of all electrical and electronical appliances (notably the one of the television and of the decoders)) that is disturbing. This lack of communication among inhabitants and thus the inhabitant's misunderstanding of the use of their housing, put at risk this new way of habitat. It brings the question to mind, will the ecodistricts cause living sickness similar to the one produced by subsidized housing?

\section{ALTERNATIVE HOUSING FORMS TO PUBLIC AND COMMERCIAL TYPOLOGIES}

Therefore new alternatives to traditional housings flourished. For the seniors, care residences, reception centers, nursing homes, short-stay centers, day care centres, night reception centers, small living units, residences for elderly people... emerge on the territory. Not only to answer the growing demand but also to offer more alternatives to the traditional way of "housing". For some others, alternative accomodation forms such as settled communities or the kangaroo house multiply today. The traditional way of inhabitating is therefore shocked and tends slowly to be replaced by the creation of new ways of living one's dwelling. A multitude of typologies live together - old and new - to satisfy the different society needs. Although the statement is alarming. The global evolution of the housing stock since the last 50 years is far from being satisfactory. According to the Federal Planning Bureau, the number of inhabitants in Wallonia should be around 3,850,000 in 2030. This represents an increasing of 270,000 people compared to the figures of $2014(3,576,325) .{ }^{16}$ The number of households should switch from $1,541,939$ to $1,729,000$ (2030) or 2,000,000 in 2060 which represents an increasing of 190,000 units for 2030 and 460,000 for 2060 (it is actually the biggest projection for Belgium within the three Regions). ${ }^{17}$ Currently Wallonia answers partially the needs by constructing 14,000 new housings each year. ${ }^{18}$ But if we desire to answer the current standards, the price of housing will rise. Would households in vulnerable situations be able to pay their house in the projected conditions?

Currently, $70 \%$ of the working population with two salaries can afford a 220,000-euro house contracting a bank loan at $4.5 \%$ during 25 years. If we analyse Johan Albrecht and Rob Van Hoofstat's ${ }^{19}$ projections, if the construction price was rising of $10 \%$ (for example following more severe energy standards such as the Passive) and would reach thus 240,000 euros, they would be only $38 \%$ households left to be able to afford it. ${ }^{20}$ It is an access to housing cut by half! This indicates that people that are working are in dropout phase and that construction

\footnotetext{
15 RENAULD Vincent, La vie en éco quartier: "C'est beau, mais y a plein de bestioles », [online] In : Le nouvel observateur, mars 2014. URL : http://rue89.nouvelobs.com/2014/03/02/ecoquartier-cest-beau-y-a-plein-bestioles-cest-crade250335 (consulted on the 05/04/2014).

16 VANDRESSE Marie et Al., Perspectives démographiques 2014-2060 - Population, ménages et quotients de mortalité prospectifs [EFPOP1460], [EN LIGNE], Bureau fédéral du Plan et Direction générale Statistique, Bruxelles, 2015 URL: http://www.plan.be/admin/uploaded/201503170937470.FORPOP1460_10926_150310_F.pdf p. 17 (consulted on the 29/09/2015).

${ }^{17}$ VANDRESSE Marie et Al., Ibid. pg. 47

${ }^{18}$ DEFFET E., « quartiers nouveaux : 400 sites en vue. » In : LE SOIR of 02/09/2015, p 4

19 ALBRECHT Johan, Rob VAN HOOFSTAT, Pénurie d'habitat. Vers une rénovation de la politique du logement, [en ligne] Itinera Institute, 2011, Bruxelles, p. 123 URL : http://www.itinerainstitute.org (consulted on the 27/9/2015)

${ }^{20}$ This calculation is based on the principle that all other elements stay equals (no evolution in household's budgets, constant purchasing power, same square meter built, maintenance of the detached house type...)
} 
based on promotion may collapse. Therefore we can imagine that a lack of housing development would accumulate by 2030 and would affect mainly vulnerable people...

Yet "the lack of housings leads sometimes to the use of non-housing buildings that don't meet the living conditions: rough construction, vehicles hastily converted, etc. for housing purposes. This produces then makeshift accommodation." ${ }^{21}$ Since the seventies, Turner ${ }^{22}$ claims the right to housing for everyone and questioned himself about the method of production of the habitat. Nowadays, these statements still haven't been able to lead to a situation improvement even if exemplary solutions such as the IBA of Berlin have emerged. Some indicators such as the multiplication of homeless and the unhappiness in big cities seems rather showing a worsening of the situation. Massive housing production is still focusing on essentially low-density stereotypes, attached social housings and standardized collective dwellings that are not adapted to the identified social transformations. This production is actually the reproduction of architectural types very little diversified that seem to be based on a misunderstanding of Durand's theories, by taking into account only the part focused on the Polytechnic School consisting on setting the building industrial production methods without consideration for his thoughts regarding space composition.

The typological approach set by Durand, still seems to be used unknowingly as a benchmark, and some principals deserve to be recalled and others to be improved. The origin of these methods can be set at the time of the emergence of the Modern Era. The Revolutionaries and more specifically the Encyclopaedists will build the basis for the scientific methods. In architecture, JLN Durand ${ }^{23}$ builds principals that are interesting to put into perspective in order to better understand the current approaches or even to reactivate or overcome some of these principles.

The publication "Recueil et Parallèle" (can be literally translated as "Collection and Parallel") of Durand expresses the principals he has followed to build his typologies. It shows how we, for the first time, switch from an architectural theory based on tradition and style reproduction to a rational theory based on systematic analysis of forms leading to scientific classification. A parallel with other scientific approaches exists, for instance the ones regarding fauna and flora classification. He would not especially go through site observation but for efficiency issues he would refer to several works from which he would extract architectural plans that he would instruct to this goal. Thus he classifies the different buildings in different "species" which are the programs. He classifies different space types according to cultural mores, practices, climates and materials. ${ }^{24}$ It is consisting thus on a synthesis of the beginning of the $19^{\text {th }}$ century of the different architecture types in space and in time. Yet, this universal approach might be put in parallel with the current massive construction of turnkeystyle buildings. It requires simply choosing a building type out of a catalogue. Some justification elements from his "collection" ("Recueil" in the original French text) (refer to the written introduction from Durand) expressly motivate his approach by a pragmatic will for

\footnotetext{
${ }^{21}$ MERLIN Pierre, définition de logement. In : Pierre Merlin et Françoise Choay, Dictionnaire de l'urbanisme et de l'aménagement, presses universitaires de France, 1988, p 442

${ }^{22}$ TURNER John F C, Robert FICHTER, Freedom to Build, dweller control of the housing process, Ed: Collier Macmillan, New York, 1972

${ }^{23}$ DURAND, Jean-Nicolas-Louis; Recueil et parallèle des édifices de tout genre anciens et modernes, remarquables par leur beauté, par leur grandeur, ou par leur singularité, et dessinés sur une même échelle, Paris, 1801

${ }^{24}$ J-L-N Durand, Précis, I, 1802, pg 1
} 
efficiency and time saving. The development of work division, mass production and process simplification announce handicraft's end and the emergence of line and prefab production. Therefore we could consider turnkey catalogues as a caricatured application of his approach. As it is the Modernism Period, it may be considered that his first architectural goal is to create mass housing. The «Cite Radieuse » («Radiant City») is a nice example or even the Villa Savoye which is above all considered as a work of art. Yet Le Corbusier's main goal was to answer the issues of his time and to create a product to multiply as his subdivision plan of Savoye Villas attests it. ${ }^{25}$

Figure 2: Sketch of Le Corbusier showing a housing development constitued of Savoye Villas (Précisions, Crès, Paris, 1930)

Image of the subdivision plan/villa Savoye

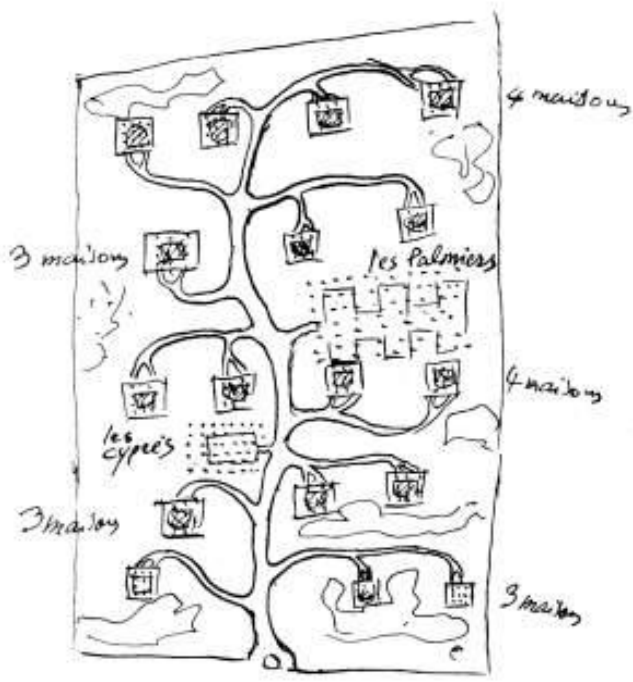

As Kaufmann ${ }^{26}$ explains it, at the end of the 18th Century with the emergence of the Neoclassicism, which is the framework in which Durand is working, the heteronomic (complex, baroque) architecture switches to an aesthetic and autonomous architecture. The composition elements are no more chained together as in Baroque but become independent from one another marking the advent of the Neoclassicism. This corresponds to the emerging rational culture. In the same vein, the social contract of Rousseau allows to each individual to become independent from his family. The same is true for the symbolic of the architectural forms.

From an industrial point of view, this corresponds also to a decomposition of tasks in order to facilitate the production. The concept of autonomy of architecture constitutes the cornerstone of Kaufmann's demonstration linking, in provocative way for that time, the aesthetic of Ledoux to the one of Le Corbusier. This autonomy indicates the independence of the building

\footnotetext{
${ }^{25}$ HUET Bernard, Sur un état de la théorie de l'architecture au XXe siècle, Ed : Quinquette, 2009, p. 55

${ }^{26}$ KAUFMANN Emil, " de Ledoux à Le Corbusier : Origine et développement de l'architecture autonome », Seuil, 2012
} 
elements but also of the buildings between each other, through the freedom in interior layouts and the use of basic geometry.

Durand stands at the crossing of two major innovations: the one of the emerging scientific approach (explaining his construction of typologies) and the one of the industrialization requiring the advent of a simple and multiplicable architecture. Considering his first scientific essence, Durand produces an inventory allowing understanding the architectural production in order to classify the different types of architecture as we classify plant and animal species.

To conclude on this ambiguity, we remind you that since the emergence of human rights, people demands of equality will rightfully generate access to housing for everyone during the states democratization after First World War. This generates mass housings that modernist architects will try to precast and to standardize. Based on a dogmatic and universalising conception of the needs, the use trend of the typologies targets the identification of a causal relation between the «universal» man and architecture: a type of person = a type of architecture. Yet nowadays, the model has become somewhat more complex.

\section{AN OTHER DEFINITION FOR HOUSING}

In the light of the apparent inadequacy between current surveys and population growing diversity, wouldn't a new typological construction consider adapted solutions?

A global and pertinent definition for our statement is the one of Pierre Merlin: "a dwelling is a group of rooms, dedicated to housing and grouping one or more persons constituting a household: a functional unity of which spatial organisation offers an answer to society standards in regards to a specified period. The dimension, the form, the internal layout, the level of equipment of the dwelling are also linked to the structure and to the economic and social level. $»^{27}$

Couldn't we suggest a redefinition that would allow incorporating in a more comprehensive way the interest of the current housing forms including the atypical ones? This redefinition would offer an enlargement of the field of survey to detect new types of habitats that would better answer the needs and expectations of our time than the massive and stereotype production generated following the Modern Architecture International Congresses.

A central point of this definition of the dictionary of Urbanism is the household. It seems that the implicit definition of it is the legal composition of the family. Yet this composition is undergoing great changes and quickly recomposes itself. By taking into account this aspect, we can expand the field of housing to " any space where a human person lives (whereas his household is officially recognized or not) » in Belgium. In this way our observations extend to many other living places. ${ }^{28}$ Therefore these spatial organizations may be used in parallel with more conventional housings. In order to structure our typology, forms are collected according

\footnotetext{
27 «un logement est un ensemble de pièces, destiné à l'habitation et regroupant une ou plusieurs personnes formant un ménage ; une unité fonctionnelle dont l'organisation spatiale offre une réponse aux normes de la société à une époque bien déterminée. La dimension, la forme, l'organisation interne, le niveau d'équipement du logement sont quant à eux, également liés à la structure et au niveau économique et social. » MERLIN Pierre, définition de logement. In : Pierre Merlin et Françoise Choay, Dictionnaire de l'urbanisme et de l'aménagement, presses universitaires de France, 1988, p 392

${ }^{28}$ These living places do not take into account the administrative and legal aspects linked to the residencial places issues which may be sometimes reduced to simple letter boxes.
} 
their possible occupation time (long term, average (transitional) term and short term). This should allow to take into account the possible affective investment and thereby to consider the possible level of requirement expected towards these types of housings.

Figure 3: Table of typologies (identification of all spaces where we are housed (spend nights)) Legend: Long term / average (transitional) term (transitional) / short term

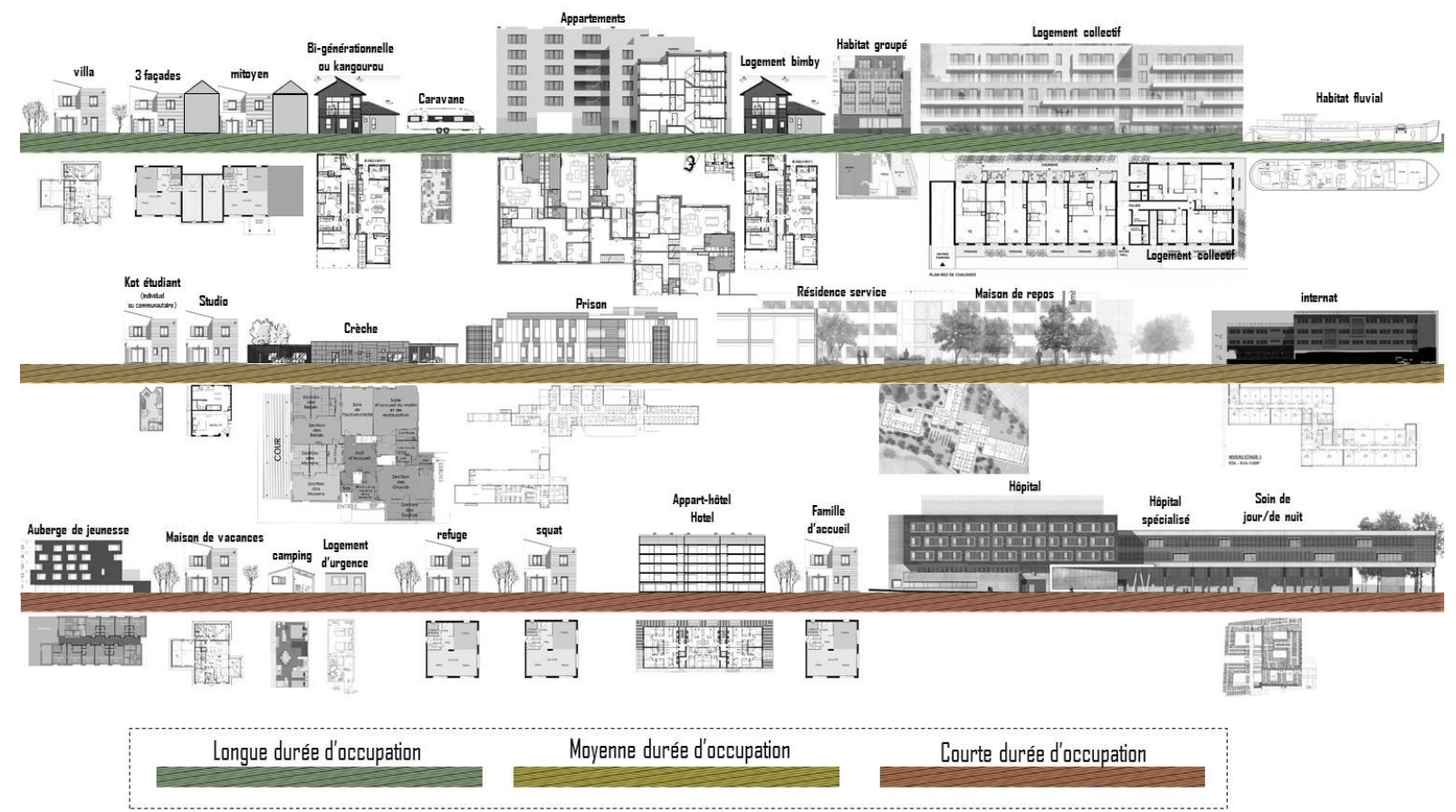

Among these, we can mention:

The group settlement, which is part of the new types of habitats, is currently emerging. It possibly comes from the crossing between the rise in property prices, the will for people with low income to become landlord, the will to build as being part of a group, and the will for a citizen's conception. It offers a clear financial benefit: all project expenses are shared (land, architect, technical team, building materials, and installation) generating a cost between 5 and $15 \%$ less than a conventional habitat ${ }^{29}$ with the same equipment. Owning property becomes possible. Furthermore, future landlords generally have a will to invest in housings layouts arranged as empty boxes to be filled according to their desires and surroundings. More and more people seem to be attracted to those initiatives and notably to the participative aspect offered by those types of projects. ${ }^{30}$

\footnotetext{
${ }^{29}$ FRAAS Serge (Architecte du projet Brutopia), Coulisses du projet Brutopia, projet de logements collectifs et participatifs, lauréat 2013 du Prix THE BLUE HOUSE/. Oral communication In : Event organised by La fondation pour les générations futures, the 3/10/2014 in Brussels

${ }^{30}$ FRAAS Serge, Ibid
} 
Out of this emerge a project that tries to take into account everyone's expectations. It naturally establishes, before even entering the housing, a better communication and confidence between neighbours. These assets will continue within the provided sharing places such as gardens, rooms, offices or garages for everyone. The mutualisation of the spaces allows for more comfort for less money. We observe a growing trend to share spaces and belongings (ex: car sharing); indeed society tends to individualise the population while, for some people, emerges a need to switch to a sharing lifestyle. ${ }^{31}$ In Belgium start more and more projects of that type as the examples of Brutopia, the Casa Nova Co-housing in Brussels or also the co-housing project in Clabecq. Seeing life's conjectures evolving wouldn't this type of habitat better answer the expectations of many Belgians?

Still little widespread, the "kangaroo" house may answer two very current issues. The first one is the desire of the elderly persons to continue their life at their place as long as possible (avoiding this way the retirement house for example). The second issue is to help persons that have difficulties to become landlord, persons with low income. ${ }^{32}$ This way, elderly persons occupy the ground floor while the first floor is used by the other part (family, student...). In the situation where there is an aged person and a student in the same dwelling: company and support is given to the senior and at the same time the student can afford a decent housing for a reasonable price. ${ }^{33}$ And when it is a family that accommodates a senior, it allows rescheduling its entry to the retirement house. ${ }^{34}$

The third example illustrates young families who cannot afford property because of the land price too high. These families search for one-floor house that they would extend with a first floor and eventually live in this extension. This alternative is very close to the Bimby spirit (Build in My Back Yard). These projects attract mainly by their financial aspect; indeed only the construction needs to be financed as the land is already paid by the owners. Unfortunately no legislation exist for the moment: many questions regarding the law are still pending: What are the rights of the two parts regarding the habitat? Regarding the land? If the aged person died, can the heirs claim ownership of the house in its entirety? How are organised the inheritance rights? So many questions do not facilitate the practical application of this new type of housing.

Nowadays housings construction is becoming more complex; many singularities are noticed through different examples. These examples are of course non-exhaustive and become more diversified with time.

Within the complexification of the society and the build environment, one of the main current trends is the demographic evolution: we live more and more long and the number of aged people is growing. The statement regarding the retirement house produced by the Roi Baudouin's Foundation ${ }^{35}$ illustrates the fact. For instance in 16 years the number of very aged

\footnotetext{
${ }^{31}$ Site du projet Brutopia. [online], URL : https://utopiabrussels.wordpress.com/the-project/ (consulted on the 25/09/2015)

${ }^{32}$ LUALABA LEKEDE Anoutcha, [en ligne] L'habitat kangourou, In: Question Santé, Edition 2007, p.3, URL: http://www.atoimontoit.be/index_htm_files/habitat_kangourou.pdf (consulted on the 20/08/2015)

${ }^{33}$ LUALABA LEKEDE Anoutcha, Ibid. pg 8

${ }^{34}$ HABITAT ET PARTICIPATION ASBL, Guide pratique habitat groupé, LLN, 2007, [online] URL : http://www.habitatgroupe.be/IMG/pdf/guide_pratique.pdf (consulted on the 20/08/2015)

${ }^{35}$ CHARLOT V., COBBAUT N., DE METS J., HINNEKINT B., LAMBERT M. pour LA FONDATION ROI BAUDOUIN, «La maison de repos du 21 ième siècle. Un lieu de vie convivial, soins inclus. À l'écoute des résidents, du personnel, de la direction, des experts. Suggestions et exemples de nouvelles initiatives », p 16 [online] URL:
} 
persons has increased by more than $37 \% !^{36}$ Ageing is an important challenge that deserves serious consideration! New alternatives to accompany seniors in their ageing emerge: residential care, day reception centres, nursing homes, short stay centres, day-care centres, night reception centres, small life units, seniority centres. These different typologies are often provided with an adapted medical accompaniment. Other type of alternative accommodations can answer the needs related to ageing: the grouped settlement, the "kangaroo" house or the concept of foster families. However another type can also be included: fostering a student at home (renting a room to avoid loneliness). We may add also caravans that, by lack of means, become illegally residences for some of them. In other words the group of seniors concerns an important part of the different emerging typologies previously identified.

Knowing the demographic projections, it is essential to answer the growing demand. Therefore a thoughtful and adapted habitat would no doubt allow to postpone if not to cancel the move to a retirement house. Can we overcome the confinement of aged people that often feel lonely at home via a thoughtful and possibly communal architecture?

An alternative to the retirement house or the loneliness of some seniors in their own residence is the collective dwelling for elderly people. This may be considered as a hybrid form of the two traditional types of habitats. It is actually a new type of accommodation dedicated to ablebodied seniors who wish to live in community. This situation can happen when for instance children leave the familial residence or when there is loss of a spouse. This system allow to people not to feel lonely and at the same time to keep their independence. It offers no additional service outside of being a residence (not as the residential care or as the retirement house). The accommodation includes generally two parts: a private zone containing a bedroom and a private living room and a communal zone including generally: kitchen, living room, bathroom... ${ }^{37}$ On a space point of view, this type of housing offers most of the time comfortable life areas as well as in terms of equipment as in terms of habitation surfaces for an affordable announced rent. ${ }^{38}$

\section{THE COMPLEXIFICATION OF THE HOUSING'S CONCEPTION METHODS IN REGARDS TO THE EMERGING NEEDS}

In the light of the multiplicity of emergent types and of the diversity of social profiles, the five classical types often exploited as a turnkey catalogue constitute an out-of-date typology that do not answer the demand. The variety of forms of housing might be compared and confronted to the conception process used. Therefore it is no more question to juggle between five basic types (attached house, detached house, semi-detached house, apartment and other minor alternatives (hospital, retirement house, etc.) but to add other existing types completing this way the demand for a diversity of ways of living.

\footnotetext{
http://www.uclouvain.be/cps/ucl/doc/aisbl-generations/documents/DocPart_Habit_MaisonRepos21eSiecle_2009.pdf (consulted on the 23/10/2013).

${ }^{36}$ CHARLOT V., COBBAUT N., DE METS J., HINNEKINT B., LAMBERT M, Ibid. pg 16

${ }^{37}$ Internet Website of the association Abbeyfield Belgium asbl . [online], URL : http://www.abbeyfield.be/fr/etre-habitant (consulted on the 29/09/2015)

${ }^{38}$ Internet Website of the association Abbeyfield Belgium asbl . Ibid.
} 
Therefore we could consider giving an answer, for instance, to lonely persons who want to stay in contact with their children without perturbation them in their housing; students who want to stay in contact with their families; sick people who want to stay close to their family...

An additional aspect should be taken into consideration: combinations (that put together two types together with one communal entrance for instance), layouts (that organize the combinations in a wise order) and hybridations (that create an other type based on two existing types) between types are possible. We will see how their wise juxtaposition or their modification generates also another form of habitat answering better the current needs. This way we would allow for a growing complexification of the possibilities in housing layouts answering probably better the intense diversity of expectations and social profiles. This approach of combination, of layout, and even of hybridation of typologies allows overcoming the stereotyped approaches from the housing industrialisation. This way a systemic logic much more complex emerges. Our housing entry key that is linked to the notion of household, lead us to consider systemic in relation with family. As Gregory BATESON seems particularly inspiring in this field and could be considered as the "grand-father" ${ }^{39}$ of the professionals in the field, the reformulation of the systemic by a group of practitioners in familial therapies could be particularly operational for our statement on housing. "Bateson insists on relations between things, on their hierarchized formal structuration, on what he calls "structure that links": everything intertwine, influence and set this way a dynamic. The system of linear causality does not stand anymore. When different elements are in interaction, the behaviour of one element becomes a "cause" for the element that follows in the interaction circuit: the linear causality becomes circular!" 40

If from each five basic types - which are the villa, the semi-detached house, the attached house, the apartment and the minor group of other housings - a set 3 sub-types are imagined in each of the five types (for instance the modest worker's housing, the average housing and the large housing moving towards the bourgeois type) linked to the kind of household; 15 combinations are possible... This logic is still causal as for each type of housing, one type of profile matches (as illustrated in Table 1).

Yet the interest to "destandardized" is to offer a variety of solutions through types combination, to answer to the lack of housing mixity on the territory (we remind you the large part of the market owned by the turnkey buildings) and to view the complexity of the variety in parallel with the more and more diverse demand of the population having different social profiles. As Turner explains it, man should not enter in boxes that are predetermined by standards (this tends to reduce housing quality instead of enhancing it), but should have the possibility to make his own choices by being involved in the production process. ${ }^{41}$ It is the reason why, inhabitants are sometimes more happy in their slum, where their social

\footnotetext{
${ }^{39}$ GAILLARD Jean-Paul, "Sur le façonnement psychosociétal en cours : enjeux psychothérapeutiques et éducatifs », Thérapie Familiale 2007/4 (Vol. 28), p. 350. DOI 10.3917/tf.074.0349

${ }^{40}$ PAESMANS Cécile, BILOCQ Céline, JULÉMONT Carine, STASSE Jerôme, Gregory Bateson, lesson notes [online], URL : http://www.systemique.be/spip/spip.php?article186 (consulted on the 29/09/2015)

${ }^{41}$ TURNER John F C, Robert FICHTER, Freedom to Build, dweller control of the housing process, Ed: Collier Macmillan, New York, 1972, p. 173-174
} 
environment suits them, rather then in a government housing that would cost more but would not answer their needs. ${ }^{42}$

If we transpose this destandardization to the spatial composition, by applying the same exercise than the one applied in classic typology on our un-standardized housing conception, we multiply the possibilities. Simply by combining the 31 different types of habitats (nonexhaustive list) to the 3 basic sub-types, the whole is clearly becoming more complex. In a systemic logic, these 93 new types can recombine with each other. If we combine only 2 types with each other, there are already $93 \times 92 / 2$ possible combinations at the start, this means 4278 new types... And by combining them 3 by 3 , the result is 129,766 new possible types. This quick calculation shows that if we accept to combine the architectural types with each other, the composition would be much more complex than our current conception methods that works with separated categories. Of course, the main goal of this calculation is not purely quantitative but is also to bring to light the qualitative aspect of the offer of housing mixity that can be offered to all the different population types.

We should stay conscious that some combinations are of course more likely than others; as a single-family house combined with a student room or even a retirement house with a care residence would be more realistic than the example of the nursery with the prison. Therefore it is no more only 15 types, but actually billions of possible combinations, hybridisable and recombinable with each other! Knowing that the basic models to be combined are probably higher than the ones considered (for instance, the inclusion of the household size, of the recomposed families, etc.) the new considered possibilities show a growing

\section{COMPLEXITY!}

The project of the Architectural Firm Vortex in Mons, initiated in 2010, shows one of the possible combination; associating, at the ground floor, a single-family dwelling and at the levels above, 4 student units. ${ }^{43}$ The Royal Institute Saint-Exupéry ${ }^{44}$, based in Leernes, illustrates also the implementation of alternatives to traditional housings. This YRS (youth residential service) host children between 6 and 18 years old. Once they are over 18, they have to leave the establishment. In order to optimize their level of independence and to ease their move, the establishment has implemented inside its structure supervised studios that children can access as soon as they are $15 .{ }^{45}$ Seeing this hybridation model between institution and conventional housing, we could consider many other pertinent types. For example, some variants are to be developed between two extremes that would be the individual house and the hospital. Some people going to hospitals do not especially need 24hrs day assistance; while others have lost their self-sufficiency mechanisms. ${ }^{46}$ The production of variants, doing the intermediate between the two basic types, would allow gaining a progressive autonomy: thus, as the children learn how to progressively leave the group, how to manage a budget, to have activities and to have their own independence; the hybrid architecture (hospital - house) would help sick persons to progressively gain their autonomy back.

\footnotetext{
42 TURNER, John FC, Le logement est votre affaire, Paris, Seuil, 1979,p. 69-80

${ }^{43}$ T.W. in Guide d'architecture moderne et contemporain 1885-2015, Mons et cœur du Hainaut, Mardaga, p 83

${ }^{44}$ Internet Website of the Institut Saint-Exupéry. [online] URL : http://www.saintexupery.be/index.php/organisat (consulted on the 29/09/2015)

${ }^{45}$ Interview with the psychlogue of the Institut Saint exupery, Leernes, Mrs Tamara Costalunga

46 Typology developed by Ornella Vanzande as part of investigations within the architectural composition section of Pierre Callewier « Mixités, laboratoire de l'habitat », project that has been awarded of the terre cuite price in 2013.
} 
Considering the extent of the issue, it is no more question of a list of types but is rather a way to deeply reconceive housing programming based on the understanding of the typologies!

\section{TOWARDS A NEW BASE OF COMPOSITION: THE CONSTRUCTION OF CROSSED TYPOLOGIES}

If we refer to the approach of Jean-Nicolas-Louis DURAND (1760-1834) who, through his Précis des leçons d'architecture given at the polytechnic school, demonstrates a methodological approach of the architectural composition. In this way, he establishes "universal" principles based on the comparison of many types. "The declination of genders, species and varieties describes thus an arc that goes from the more general to the more particular, from the more universal to the more local" ${ }^{47}$ His goal is to search for the best model to copy. He announces the industrialisation of architecture - we could, this way, repeat models by slightly adapting them - almost as turnkey catalogues do today. In this way, Durand is the first to suggest a systematic approach: "decomposing to analyse, decomposing in parts and elements that are comparative supports. Durand breaks down the building; he isolates the constituents according to the considered programme and according to a systematic composition method". ${ }^{48}$ Therefore he joins the position already expressed by the Quatremère de Quicy ${ }^{49}$ for whom "genius does not consist on inventing new elements but on inventing new combinations of these elements always the same, and these combinations are infinitely variable." ${ }^{50}$ The compositions and/or the articulations between different elements in the architectural composition are highlighted in Durand's words, more than their inherent qualities.

According to Jacques Lucan, the systematic theory of Durand is composed of three determining factors that constitute the base of his pedagogy ${ }^{51}$ : the historical models, unanimously recognised references; the types, based on those references, constitute the universal principles; the method, or the art to articulate these elements each other. Although Durand's approach is broadly contested and criticised, Lucan reminds us that he is still a referent in the composition theory. In this way, Lucan traces the parallel with the syntax; undifferentiated elements serve multiple arrangements via the multiplicity of combinations and assemblies. "The parallel between these elements can also become a preparatory phase for the implementation of a project (...). Each of these plans (including the one of the Château of Versailles, of the Rohan Palace, etc.) reclaims the general arrangement of a referent castle or palace by adopting its typology, which means the arrangements of the parts and courts, their relationships and their contrasts but without care for its geometry." ${ }^{52}$. In this sense, the parallel between different projects allows the preliminary analysis of space composition and then opens up perspectives on the possibilities to create a project while using and mixing the different elements each other.

\footnotetext{
${ }^{47}$ DURAND J-L-N, Précis, 1, 1802, pg 1

${ }^{48}$ LUCAN Jacques, Composition, non-composition, Architecture et théories, $19 e-20 e$ siècles, Presses polytechniques et universitaires romandes, Lausanne, 2009, pg 34

${ }^{49}$ QUATREMÈRE DE QUINCY Antoine-Chrysostome, Encyclopédie méthodique, Architecture, Paris, 1788, « Cabane », p. 385.

${ }^{50}$ LUCAN Jacques, Ibid., pg 35-36

${ }^{51}$ LUCAN Jacques, Ibid., pg 48

${ }^{52}$ LUCAN Jacques, Ibid., pg 46
} 
By positioning ourselves on that last point, on the continuity of Durand's and Lucan's principles, our analysis differs itself in different points.

1. The empirical approach is specifically tested from a housing redefinition.

2. Besides the questions of combination and arrangements that we extend, we look at crossing this directly with the users. By combining different types with each other, the aim is to create other types, and sub-types answering better the current society needs.

3. This comes to the development of a double crossed typology: the one of housing types and the one of users types.

\section{CONCLUSION: FOR A CREATIVE USE OF THESE CROSSED TYPOLOGIES}

It is clear that in the light of the current trends and society evolutions (social, environmental, economic, cultural), it is important to focus on conception methods as well as on today's emergent typologies. The structure of the NSI survey shows a very little number of housing types on the territory. This conclusion is questionable as it is possible for some habitat forms to be much more present than what the numbers reveal. The identified emergent types are hidden in sub-categories to the benefit of an apparent uniformisation of types. For instance the kangaroo house of the Modern and Contemporary Architecture Guide could be classified under the single-family house section. If it is possible to state that new housing forms are emerging, it is hard to see if the phenomenon overcome in numbers the $3 \%$ of unknown in statistics.

These typologies cannot be in any case detached from the typo-morphological notion of the territory. It is for operational purposes of the analysis that, at this state, to break down the system, the morphological aspect is not taken into account. Of course, in order to offer an adequate answer on the territory, typologies should talk and communicate to each other and come together.

Besides the elderly user type, other types should be more deeply explored. The core of the prospects opened up by this research is not only to move the problem from the quantitative production issues to quality in typological proposals, it is also to think about the programming. This issue goes through the crossed typologies allowing including upstream the order that architects and other building technicians could enhance. The reason for the weak programmatic originality, illustrated in our survey based on the Modern and Contemporary Architecture Guide (which appears potentially rich in innovations), is better explained through the program definition rather than through the architectural composition issue.

This concerns the habitat conception process and implementation issue. These current processes do not seem appropriated to answer the needs because they go through stereotypes solutions that do not exploit the interest of combinations, arrangements and hybridations that proposed crossed typologies do. The issue extends to the correct articulation between the evolving demands, the spatial composition offering new perspectives, the stereotyped offer on the market and the regulation still too much based on standards that do not specially answer the current expectations. A way to heighten awareness amongst the inhabitants to the challenge of building freely their own housing identified by Turner: his famous "Freedom to build". 


\section{Keywords :}

Housing evolution, architectural typology, way of inhabitating, adapted home, citizen participation, complexity and hybridation

\section{BIBLIOGRAPHIE}

DESMEDT I., BEN DJAFFAR L., Guide d'architecture moderne et contemporaine 1885-2015, Mons et cour du Hainaut, Ed. Mardaga and the architecture section of the Federation of Wallonia-Brussels, 2015.

DURAND, Jean-Nicolas-Louis; Recueil et parallèle des édifices de tout genre anciens et modernes, remarquables par leur beauté, par leur grandeur, ou par leur singularité, et dessinés sur une même échelle, Paris, 1801.

DURAND, Jean-Nicolas-Louis, Précis, I, 1802

HUET Bernard, Sur un état de la théorie de l'architecture au XXe siècle, Ed : Quinquette, 2009.

KAUFMANN Emil, «de Ledoux à Le Corbusier: Origine et développement de l'architecture autonome », Seuil, 2012.

LUCAN, Jacques, Composition, non-composition, Architecture et théories, $19 e-20 e$ siècles, presse polytechniques et universitaires romandes, Lausanne, 2009.

MERLIN Pierre, CHOAY Françoise, Dictionnaire de l'urbanisme et de l'aménagement, presses universitaires de France, 1988.

QUATREMÈRE DE QUINCY Antoine-Chrysostome, Encyclopédie méthodique, Architecture, Paris, 1788, «Cabane ».

TURNER, John FC, Housing by people , London : Maryon Boyars Publishers, traduction française: «Le logement est votre affaire», Paris : Seuil, 1979 (1976).

TURNER, John FC, Robert FICHTER, Freedom to Build, dweller control of the housing process, Ed: Collier Macmillan, New York, 1972.

\section{AUTRES}

ALBRECHT Johan, Rob VAN HOOFSTAT, Pénurie d'habitat. Vers une rénovation de la politique du logement, Itinera Institute, 2011, Bruxelles, 320 p. URL : http://www.itinerainstitute.org

BAILLON Quentin dans L'habitat face aux évolutions des modes de vie en Europe: quels enseignements, Mars 2012, Lyon. [En ligne] Pratiques européennes, URL:

http://www.urbalyon.org/AffichePDF/Reperes_europeens_-_seance_du_22_mars_2012___

habitat_face_aux_evolutions_des_modes_de_vie_en_Europe_-_quels_enseignements_--_seance_du_22_mars_2012--3421

BERNARD Yvonne L'habitat à l'épreuve de la réalité pratique. Quelques hypothèses prospectives [en ligne] http://www.habiter-autrement.org/01_tendances/06_tend.htm (consulté le 1509 2015)

Brutopia (website of the project). [online], URL : https://utopiabrussels.wordpress.com/the-project/

CHARLOT V., COBBAUT N., DE METS J., HINNEKINT B., LAMBERT M. pour LA FONDATION ROI BAUDOUIN, "La maison de repos du 21ième siècle. Un lieu de vie convivial, soins inclus. À l'écoute des résidents, du personnel, de la direction, des experts. Suggestions et exemples de nouvelles initiatives », 125 pg [online] URL: http://www.uclouvain.be/cps/ucl/doc/aisblgenerations/documents/DocPart_Habit_MaisonRepos21eSiecle_2009.pdf 
COENE G., VANHEE N., Construire ou rénover: plaisir ou fardeau, In : Test achat (set on line 01/03/2006) URL: http://www.test-achats.be/maison-energie/nc/article/notre-grande-enquete-sur-la-construction.

DEFFET E., « quartiers nouveaux : 400 sites en vue. » In : LE SOIR of the 02/09/2015

DESSOUROUX C., ROMAINVILLE A., La production de logements en Belgique et à Bruxelles Acteurs, dynamiques, géographie, [EN LIGNE] In: EchoGeo, 15|2011: décembre 2010/février 2011, URL : https://echogeo.revues.org/12279?lang=en

DREYER Pascal, Limiter les conséquences de la vieillesse et de la dépendance, Agir sur l'habitat et l'environnement. 216 pg [online] In : Gérontologie et société, 2008/2, Fond. Nationale de Gérontologie - nº 125 URL : http://www.cairn.info/revue-gerontologie-et-societe-2008-2-p-167.htm

FRAAS Serge (Architecte of the project Brutopia), Coulisses du projet Brutopia, projet de logements collectifs et participatifs, lauréat 2013 du Prix THE BLUE HOUSE/. Communication orale In : Event organised by the Foundation For Future Generations, on the 3/10/2014 in Bruxelles

GAILLARD Jean-Paul, Sur le façonnement psychosociétal en cours : enjeux psychothérapeutiques et éducatifs, Thérapie Familiale 2007/4 (Vol. 28), p. 349-367350. DOI 10.3917/tf.074.0349

HABITAT ET PARTICIPATION ASBL, Guide pratique habitat groupé, LLN, 2007, [online] URL : http://www.habitat-groupe.be/IMG/pdf/guide_pratique.pdf

INS DONNEES STATISTIQUES «Logements privés occupés selon le type de logement et le type de bâtiment » table 00.402001

Institute Saint-Exupéry. (internet website) [online] URL :http://www.saintexupery.be/index.php/organisat

Larousse, version informatisée, [online], URL :http://www.larousse.fr/dictionnaires/francais/logement/47655

LUALABA LEKEDE Anoutcha, [online] L'habitat kangourou, In : Question Santé, Edition 2007, 20 pg, URL : http://www.atoimontoit.be/index htm files/habitat kangourou.pdf

RENAULD Vincent, La vie en éco quartier: "C'est beau, mais y a plein de bestioles », [ONLINE] In : Le nouvel observateur, march 2014. URL: http://rue89.nouvelobs.com/2014/03/02/ecoquartier-cest-beau-y-aplein-bestioles-cest-crade-250335

PAESMANS Cécile, BILOCQ Céline, JULÉMONT Carine, STASSE Jerôme, Gregory Bateson, lesson notes [online], URL : http://www.systemique.be/spip/spip.php?article186

VANDAMME Thomas, Le contexte de la maison individuelle en Belgique, Faculty of Architecture and Urbanism of the University of Mons, mémoire en vue de l'obtention du diplôme d'architecture, $2014,193 \mathrm{p}$

VANDRESSE Marie et Al., Perspectives démographiques 2014-2060 - Population, ménages et quotients de mortalité prospectifs [EFPOP1460], $74 \mathrm{p}$ [ONLINE], Bureau fédéral du Plan et Direction générale Statistique, Bruxelles, 2015, URL :http://www.plan.be/admin/uploaded/201503170937470.FORPOP1460_10926_150310_F.pdf

VANNESTE D., THOMAS I., GOOSSENS L., Le logement en Belgique : enquête socio-économique 2001. 211pg [ONLINE] URL: http://statbel.fgov.be/fr/binaries/mono_200102_fr\%5B1\%5D_tcm326-35799.pdf. 


\section{FIGURES}

Figure 1 Typologies of the current housings

Picture house elevation (google picture) URL :http://www.habitatdavenir.com/maisons-muse/t5-r1/

Picture apartment (google imqge) URL : http://cargocollective.com/marinebeaumanoir/Une-Valse-a-Mille-Temps

Picture hospital (google image) URL: http://www.google.be/imgres?imgurl=http://sa13.fr/IMG/jpg/facade-color-nhapweb.jpg\&imgrefurl=http://sa13.fr/spip.php?article96\&h=167\&w=780\&tbnid=KWbkgRcFQ8yYLM:\&docid=s_5SXvW Q7BP5IM\&ei=oRcBVtqgAobaUYaFvoAF\&tbm=isch\&ved=0CE0QMyhKMEo4ZGoVChMImvWz1qKKyAIVBm0UC h2Ggg9Q

Figure 2: $\quad$ Sketch of Le Corbusier showing a housing development constitued of Savoye Villas (Précisions, Crès, Paris, 1930)

Image og the subdivision plan /villa Savoye URL : http://www.nogoland.com/urban/publications/urbanisme.htm

Figure 3: Table of all typologies (identification of all places were we are housed (spend the night) 